\title{
The effects of writing a gratitude letter on life satisfaction
}

\author{
Chisa Hosaka (Faculty of Letters, The University of Tokyo, peanuts.19990313@gmail.com) \\ Yuko Shiraiwa (School of Health and Social Services, Saitama Prefectural University, shiraiwa.y@gmail.com)
}

\section{感謝の手紙を書くことが人生満足度に与える影響}

保坂 知沙（東京大学 文学部）

白岩祐子（埼玉県立大学 保健医療福祉学部）

\section{要約}

感謝の手紙や文章を書くなど、他者への感謝を喚起する介入が主観的幸福感に与える正の効果は、これまで国外の実証 研究で確認されてきた。しかし国内では、検討されてきたものの介入の効果はまだ確認されていない。その理由として、 感謝に付随して生じる心理的負債感が日本人の場合とくに強く、これが感謝の効果を相殺するためだと考えられてきた。 また、感謝を喚起する複数の介入の中でもとくに手紙を書くのが有効だと予想されているが、研究によっては必ずしも 予想どおりの結果が得られているわけではない。その一因として、当該研究が複数の介入条件に一律に課している制限 時間が短いことが挙げられるだろう。感謝について思考したり、感謝を文章にしたり、感謝の手紙を書いたりする各条 件のなかで、手紙を書くことは思考、表現、伝達の全要素を含むもつとも複合的な作業といえる。したがって一律に短 い制限時間を課すことは、とくに手紙を書く条件に不利に働く可能性がある。先行研究にもとづき、本研究は感謝 3 条 件（感謝の手紙を書く／文章を書く／思考する）と統制条件（部屋のレイアウトを書く）の主観的幸福感を比較したが、 以上の二点をふまえ、(1)時間制限ではなく文字数制限を課す、(2)個人特性としての心理的負債感を測定し、その効果を 統制する、という変更を加えてオンライン実験を行った。主観的幸福感 (人生満足度)を従属变数とする重回帰分析の結果、 想定どおり、感謝の手紙を書く条件に有意な正の効果が見いだされた。この結果にもとづき、感謝研究の今後の方向性 が議論された。

\section{Key words}

gratitude, gratitude interventions, letters, well-being, positive psychology

\section{Introduction}

\subsection{Gratitude and well-being}

Empirical studies have shown that gratitude is a consistent predictive factor of well-being (Jans-Beken, Jacobs, Janssens, Peeters, Reijnders, Lechner, \& Lataster, 2020; Sheldon \& Lyubomirsky, 2006; Wood, Froh, \& Geraghty, 2010). To examine the effects of gratitude on well-being, Watkins, Woodward, Stone, and Kolts (2003, Study 4) randomly assigned participants to one of four tasks: three gratitude interventions ("thinking about someone they were grateful to," "writing a gratitude essay," "writing a gratitude letter") and a control task ("writing about the lay-out of their living room"). The results of generalized linear model (GLM) with these interventions and time points (pre/post intervention) as independent variables and positive affect as the dependent variable revealed a main effect for time points and a significant interaction. The subtests showed that the three gratitude interventions increased positive affect, but the control task did not.

There are a variety of interventions to induce and enhance gratitude as mentioned above, and especially writing a gratitude letter is expected to have a substantial effect. Though the interventions in Watkins et al. (2003) did not have the greatest effect, writing a gratitude letter is widely believed to be effective. Toepfer and Walker (2009) asked participants to write three gratitude letters over an 8-week period, and consequently, subjective happiness in the experimental group (letter writers) significantly increased compared to the control group (non-letter writers). Similarly, Toepfer, Cichy, and Peters (2012) confirmed that writing gratitude letters increased life satisfaction.

The positive effects of gratitude on well-being have not yet been demonstrated in Japan (Tomita \& Anbo, 2018). A study in which participants were instructed to look back on the day and to write about "gratitude," "hassles" and "daily events" according to a randomly assigned condition for three weeks did not find the positive effect of gratitude on well-being (Aikawa, Yada, \& Yoshino, 2013). Another study that examined the effect of expressing gratitude in school children did not confirm its positive effect either (Iida, Shindo, \& Takigawa, 2018).

1.2 Issues from previous studies and the purpose of this study

Watkins et al. (2003) explained that in their study the letter did not have the expected prominent effect because the writers were probably worried about how the benefactors would react to the letters. Apart from this, it is likely that the time limit was an issue. The time allocated for each task was only five minutes. It is possible that the expected effects could not be obtained as five minutes were not enough to write a letter, a task which requires 
the subject to remember, think, express, and communicate at the same time. If so, a better approach is to set the limit on the quantity of writing (number of words or characters), not the time.

Moreover, as the explanations of the results of studies in Japan, which have not confirmed the effects of gratitude as stated earlier, problems of cultural sensitivities on how gratitude is felt or expressed have been pointed out. Japanese particularly tend to feel burdened by debt to a gratitude partner, which may offset the positive effects of gratitude (Aikawa, 2016). Thus, in examining the positive effects of gratitude in Japanese people, it is presumably important to control for the negative effect of indebtedness.

The present study aimed to test the hypothesis that thanking someone, especially writing a gratitude letter, enhances one's well-being, and basically replicated Watkins et al. (2003), which used three gratitude interventions (gratitude thinking/essay/ letter) and a control activity. To mitigate the social anxiety produced by imagining how the benefactors will receive the letters, letters written by participants who wrote a letter were not actually given to the benefactors. We set the lower and upper limits on the number of characters so that participants in the three conditions that require writing (essay/letter/control) could write without worrying about time. We also measured the tendency to feel indebted as a personal trait to control for its effect on wellbeing.

The present study focused on life satisfaction as an index of well-being. Subjective well-being has been considered to be synonymous with happiness (Keltner \& Simon-Thomas, 2020). Happiness is defined as frequent positive affect, high life satisfaction, and infrequent negative affect (Lyubomirsky, Sheldon, $\&$ Schkade, 2005). These three constructs are the components of subjective well-being as well (Diener, Suh, Lucas, \& Smith, 1999). Not all of these three components have been used in gratitude studies, but they have been selectively used according to study purposes. For example, PANAS (Positive and Negative Affect Scale; Watson, Clark, \& Tellegen, 1988) has often been used to evaluate positive/negative affect (Watkins et al., 2003) and Satisfaction With Life Scale (Diener, Emmons, Larsen, \& Griffin, 1985) to evaluate life satisfaction (Aikawa et al., 2013; Toepfer et al., 2012; Toepfer \& Walker, 2009). We focused on life satisfaction as a construct of well-being under the assumption that gratitude ${ }^{(1)}$ to others not just influences affects but also enhances the general sense of satisfaction.

\section{Methods}

\subsection{Procedure}

An online experiment using Qualtrics was conducted from November to early December 2020.(2) Tendency to feel indebted and dependent variable before intervention (Life Satisfaction Pre) were measured in the first questionnaire. A week later, the second questionnaire was sent to participants, in which they were randomly assigned to one of four tasks: three gratitude tasks (letter/essay/thinking) and a control task. After completion of all tasks, dependent variable after intervention (Life Satisfaction_Post) and the demographic variables (age/gender) were measured.

In the three gratitude tasks, participants were asked to think of one person they were grateful to at first. Then, they were given instructions according to their task. For the letter writing participants the instruction was: "Write a letter to that person assuming you will give it to him/her. Remember concrete details of what he/she did for you and begin your letter with the addressee." The essay writers were asked to: "Write about why you are grateful to him/her. Remember concrete details of what he/she did for you and begin your essay with a title." The thinking task instruction was: "Think about why you are grateful to him/her. Remember clearly the concrete details of what he/she did for you." The control group was asked to observe the room they were in and "describe the layout of the room with as much detail as possible" in writing. Participants with the three writing tasks wrote in any format with a word limit of 150 to 300 characters. The thinking task participants were given at least 70 seconds between reading the instructions and answering the questions.

\subsection{Measures}

\subsubsection{Indebtedness}

To assess indebtedness, we used a scale constructed by Aikawa and Yoshimori (1995), which measures individual differences in the tendency to feel indebted, that is, to what extent one feels obliged to others on receiving favors or assistance. The scale consists of 18 items (e.g., "If someone does me a favor, I should return it.") on 6-point Likert-type scales ( 1 = Strongly disagree, $6=$ Strongly agree). We calculated the total scores as variables. Higher total scores on this measure indicate higher inclination for indebtedness.

\subsubsection{Life satisfaction}

To measure life satisfaction, we used a Japanese version of the Satisfaction With Life Scale (Sumino, 1994), which was developed based on Diener et al. (1985). Subjective well-being is composed of emotional/affective and cognitive/judgmental aspects, of which the latter corresponds to life satisfaction (Sumino, 1994). Life satisfaction is defined as an individual's subjective and personal judgment of well-being and quality of life as a whole based on self-determined criteria. The scale includes five items (e.g., "I am satisfied with my life.") on 7-point Likert-type scales $(1=$ Strongly disagree, $7=$ Strongly agree $)$. We calculated the total scores as variables. Higher total scores on this measure indicate greater satisfaction with life.

\subsection{Participants}

We asked acquaintances of the first author to participate in 
the experiment. A total of 129 Japanese youngsters in their early twenties, mainly students, participated. Of these, we excluded 34 people who did not access to the second questionnaire and 11 people who were found to have answered inaccurately in the manipulation check of intervention. ${ }^{(3)}$ Thus, the data of 84 people (45 men, 37 women, and 2 unknown individuals) were used for analysis. The mean age was $21.81(S D=0.87)$ (valid response rate was $65.12 \%$ ). The number of valid responses for each task was $n=24$ in the letters, $n=17$ in the essays, $n=20$ in the thinking task, and $n=23$ in the control task, respectively.

This experiment was conducted after undergoing the university ethical review and with the consent of the participants.

\section{Results}

We used the HAD (Shimizu, 2016), a statistical analysis software for analysis. Table 1 displays a summary of the variables. The means $(S D S)$ of the value of Life Satisfaction_Post minus Life Satisfaction_Pre were $1.79(0.63)$ in the letters, 0.06 (0.74) in the essays, $1.15(0.69)$ in the thinking task, and 0.22 (0.64) in the control task. The benefactors mentioned in the three gratitude activities were mothers $(n=27)$, friends $(n=13)$, fathers $(n=6)$, lovers $(n=5)$, grandparents $(n=3)$, and others $(n$ $=7)$.

A result of an ANOVA, in which condition was entered as an independent variable and Life Satisfaction_Pre as a dependent variable, did not find any significant effect $(F(3,80)=1.33$, n.s.).

We first used a 4 (Condition) $\times 2$ (Time: pretreatment and post-treatment) ANOVA for life satisfaction. The results showed a significant main effect for time $\left(F(1,80)=5.67, p<.05, \eta^{2}=\right.$
$.07)$, which was due to post-treatment life satisfaction scores being higher than pretreatment scores. There was neither a significant main effect of condition $(F(3,80)=1.68, n . s$. $)$ nor condition $\times$ time interaction $(F(3,80)=1.52, n$.s. $)$ for life satisfaction.

To examine the effects of interventions by controlling the effect of indebtedness, we conducted a multiple regression analysis. Gratitude thinking $(1=$ letter/essay/thinking, $0=$ control $)$, gratitude expression ( $1=$ letter/essay, $0=$ others $)$, gratitude communication $^{(4)}(1=$ letter, $0=$ others $)$ were entered as independent variables, and indebtedness, gender $(1=$ women, $0=$ men $)$, and age as control variables, and the value obtained by subtracting Life Satisfaction_Pre from Life Satisfaction_Post and dividing by the former as dependent variable. The results revealed significant effects for gratitude communication $(\beta=.31, p<.05)$ and for indebtedness $(\beta=-.24, p<.05)$ (Table 2). All VIFs were less than 2.50 .

\section{Discussion}

The current study tested the hypothesis that the three gratitude interventions, especially writing a gratitude letter, enhances well-being. By controlling for indebtedness, we found that writing a gratitude letter has a positive effect.

\subsection{Implications of the present study}

This study presents the following two implications. First, it shows the necessity of measuring and controlling indebtedness. The results of this study confirm that Japanese people in particular tend to feel dutifully obliged and indebted to the person they are grateful to, which may offset the positive effects of gratitude (Aikawa, 2016). Effects of gratitude on well-being could have

Table 1: Summary statistics of variables

\begin{tabular}{lccccc}
\hline \multicolumn{1}{c}{ Variable } & Mean & SD & Min. & Max. & Theoritical Max. \\
\hline Indebtedness & 75.55 & 8.12 & 59 & 100 & 108 \\
Life Satisfaction_Pre & 23.37 & 5.41 & 5 & 35 & 35 \\
Life Satisfaction_Post & 24.23 & 4.84 & 7 & 34 & 35 \\
\hline
\end{tabular}

Table 2: Results of multiple regression analysis for life satisfaction ((Post-Pre)/Pre)

\begin{tabular}{lc}
\hline & Standardized coefficients $(\beta)$ \\
\hline Thinking $(1=$ letter/essay/thinking, $0=$ control $)$ & .16 \\
Expression $(1=$ letter/essay, $0=$ others $)$ & -.23 \\
Communication $(1=$ letter, $0=$ others $)$ & $.31 *$ \\
\hline Indebtedness & $-.24 *$ \\
Gender $(1=$ women, $0=$ men $)$ & .15 \\
Age & .05 \\
\hline$F$ & 1.65 \\
$R^{2}$ & .12 \\
Adjusted $R^{2}$ & .05 \\
\hline
\end{tabular}

Note: $* p<.05$. 
been identified in previous studies in Japan (Aikawa et al., 2013; Iida et al., 2018) if indebtedness had been controlled for.

Second, our results suggest that just thinking or writing about gratitude is not enough to improve well-being and that it is communicating (composing a gratitude letter to the benefactor) that brings the positive effect of gratitude interventions. This result is partially consistent with previous studies (Toepfer \& Walker, 2009). One potential explanation for this is that the act of writing a gratitude letter is an intentional activity. As Toepfer and Walker (2009) and Lyubomirsky, Dickerhoof, Boehm, and Sheldon (2011) have indicated, it is possible that the act of writing a gratitude letter enhanced the well-being of the participants by introducing an intentional activity (Fordyce, 1977, 1983), which presumably intensified their gratitude and motivated them to communicate it even if the activity was initiated on instructions of the researcher.

\subsection{Significance of this study and future directions}

Our findings showed that writing a gratitude letter, a very ordinary and simple act, has a positive effect. The results also suggest that writing one gratitude letter is enough to obtain benefits, while previous studies conducted a series of multiple interventions (Toepfer \& Walker, 2009). Additionally, we found that the letter does not necessarily have to be written by hand and that it is effective even when written online, as in this study. Furthermore, the letter does not have to be long; we found that even a short letter of 150-300 characters produces a positive effect. In summary, the current study has practical significance in that it revealed how well-being can be boosted by writing a gratitude letter, a simple ordinary act that is hassle-free and is also effective when used through contemporary means such as email.

Further research is needed to deepen the understanding of the effects of gratitude letters. First, we need to compare the impact of the benefactor and the content of gratitude letter on well-being. We found that many participants in this study chose parental figures, mostly the mother, as the person they were grateful to. Comparing a gratitude letter's effect on wellbeing based on the relationship between the participant and benefactor and the nature of the benefits for which gratitude is expressed, could produce some valuable insights. Second, the optimal frequency and length of gratitude letters must be determined. Third, additional work is needed to examine the effect of "savoring". The literature concerning gratitude interventions suggests that it is important to encourage participants to "savor" their gratitude (Aikawa et al., 2013; Jose, Lim, \& Bryant, 2012). "Savoring" is a construct developed in the field of positive psychology, which is defined as a practice in which people engage "to attend to, appreciate, and enhance the positive experiences in their lives" (Aikawa et al., 2013; Bryant \& Veroff, 2007; Jose et al., 2012). Future research will benefit by focusing on this "savoring", which seems to be one of the keys to make the most of gratitude. Such studies can build on the present study and help shed light on the multi-faceted utility of gratitude and gratitude letters.

\section{Acknowledgements}

This work was supported by JSPS KAKENHI Grant Number JP17K04310.

\section{Notes}

(1) The feeling of gratitude is composed of a sense of wonder, thankfulness, and appreciation (Emmons \& Shelton, 2002).

(2) Based on previous research suggesting that writing methods have no significant effect on content (Hartley, Sotto, \& Pennebaker, 2003).

(3) In the gratitude essay intervention, there were 5 participants who wrote gratitude letters instead of essays. This mistake presumably happened because we used the word "composition," a broad term which could have been misinterpreted, in the instructions. In future studies, it must be ensured that the instructions are precise and clear.

(4) Here the word "communication" is used based on the fact that the letter writing participants wrote a letter assuming that they would "communicate" their gratitude to a real recipient, which made an essential difference between the letter condition and the others like essay writing.

\section{References}

Aikawa, A. (2016). Is well-being improved by appreciating one's life? Japanese Journal of Motivational Studies: IMSAR annual Report, (5), 54-67. (in Japanese)

Aikawa, A., Yada, S., \& Yoshino, Y. (2013). An interventional experiment on the effect of counting gratitude on subjective well-being. Bulletin of Tokyo Gakugei University, 64 (1), 125-138. (in Japanese with English abstract)

Aikawa, A. \& Yoshimori, M. (1995). An attempt to construct a scale to measure sensibilities to indebtedness. Japanese Journal of Social Psychology, 11 (1), 63-72. (in Japanese with English abstract)

Bryant, F. B. \& Veroff, J. (2007). Savoring: A new model of positive experience. Mahwah, NJ, US: Lawrence Erlbaum Associations.

Diener, E. D., Emmons, R. A., Larsen, R. J., \& Griffin, S. (1985). The satisfaction with life scale. Journal of Personality Assessment, 49 (1), 71-75.

Diener, E., Suh, E. M., Lucas, R. E., \& Smith, H. L. (1999). Subjective well-being: Three decades of progress. Psychological Bulletin, 125 (2), 276-302. https://doi.org/10.1037/00332909.125.2.276.

Emmons, R. A. \& Shelton, C. M. (2002). Gratitude and the science of positive psychology. Handbook of Positive Psychology, 18, 459-471.

Fordyce, M. W. (1977). Development of a program to increase 
personal happiness. Journal of Counseling Psychology, 24 (6), 511-521.

Fordyce, M. W. (1983). A program to increase happiness: Further studies. Journal of Counseling Psychology, 30 (4), 483498.

Hartley, J., Sotto, E., \& Pennebaker, J. (2003). Speaking versus typing: A case-study of the effects of using voice-recognition software on academic correspondence. British Journal of Educational Technology, 34 (1), 5-16.

Iida, K., Shindo, T., \& Takigawa, S. (2018, September). Effect of expressing gratitude on recognition of interpersonal relationship and well-being in elementary school children. Proceedings of the Annual Convention of the Japanese Psychological Association. The 82nd annual convention of the Japanese Psychological Association, 82, 3PM-097. (in Japanese)

Jans-Beken, L., Jacobs, N., Janssens, M., Peeters, S., Reijnders, J., Lechner, L., \& Lataster, J. (2020). Gratitude and health: An updated review. The Journal of Positive Psychology, 15 (6), 743-782.

Jose, P. E., Lim, B. T., \& Bryant, F. B. (2012). Does savoring increase happiness? A daily diary study. The Journal of Positive Psychology, 7 (3), 176-187.

Keltner, D. \& Simon-Thomas, E. (2020). Terms of happiness: Definitions. The science of happiness (edX: BerkeleyX GG101x). Retrieved December 27, 2020 from https://learning.edx.org/course/course-v1:BerkeleyX+GG101x+1T2020/ block-v1:BerkeleyX+GG101x+1T2020+type@sequenti al+block@25cab547f97947e5862b71756ce490da/blockv1:BerkeleyX+GG101x+1T2020+type@vertical+block@82 d7f45507d746e899007a24e3bd20c2.

Lyubomirsky, S., Dickerhoof, R., Boehm, J. K., \& Sheldon, K. M. (2011). Becoming happier takes both a will and a proper way: An experimental longitudinal intervention to boost well-being. Emotion, 11 (2), 391-402.

Lyubomirsky, S., Sheldon, K. M., \& Schkade, D. (2005). Pursuing happiness: The architecture of sustainable change. Review of General Psychology, 9 (2), 111-131.

Sheldon, K. M. \& Lyubomirsky, S. (2006). How to increase and sustain positive emotion: The effects of expressing gratitude and visualizing best possible selves. The Journal of Positive Psychology, 1 (2), 73-82.

Shimizu, H. (2016). An introduction to the statistical free software HAD: Suggestions to improve teaching, learning and practice data analysis. Journal of Media. Information and Communications, 1, 59-73. (in Japanese with English abstract)

Sumino, Z. (1994, August). Development of the Japanese version of the Satisfaction with Life Scale [SWLS]. In Proceedings of the 36th annual meeting of the Japanese Association of Educational Psychology, 192. (in Japanese, translated by the author of this article)

Toepfer, S. M., Cichy, K., \& Peters, P. (2012). Letters of grati- tude: Further evidence for author benefits. Journal of Happiness Studies, 13 (1), 187-201.

Toepfer, S. M. \& Walker, K. (2009). Letters of gratitude: Improving well-being through expressive writing. Journal of Writing Research, 1 (3), 181-198.

Tomita, Y. \& Anbo, H. (2018, September). Development of effective gratitude intervention in Japan. To focus on the characteristic of the subject. The 82nd annual convention of the Japanese Psychological Association, 3EV-033. (in Japanese)

Watkins, P. C., Woodward, K., Stone, T., \& Kolts, R. L. (2003). Gratitude and happiness: Development of a measure of gratitude, and relationships with subjective well-being. Social Behavior and Personality: an International Journal, 31 (5), 431-451.

Watson, D., Clark, L. A., \& Tellegen, A. (1988). Development and validation of brief measures of positive and negative affect: The Panas scales. Journal of Personality and Social Psychology, 54 (6), 1063-1070.

Wood, A. M., Froh, J. J., \& Geraghty, A. W. (2010). Gratitude and well-being: A review and theoretical integration. Clinical Psychology Review, 30 (7), 890-905.

(Received February 23, 2021; accepted April 5, 2021) 